As previously published for Ruminants, the worm population does not appear as normally distributed. Parameters such as geometrical mean or median are more valid than the classical arithmetic mean.

On these relatively old animals we were not able to con firm the linear relationship egg-counts/ worm-counts established on growing pigs by TAFFs et al. (1969).

\title{
ÉTUDE ÉPIDÉMIOLOGIQUe DE LA MALADIE D'AUJESZKY EN FRANCE PAR REGHERGHE DES ANTICORPS NEUTRALISANTS
}

\author{
B. TOMA, P. GORET et J.-J. BENET \\ Laboratoire des Maladies contagieuses, I. N. R. A., \\ École nationale vétérinaire de Maisons Alfort, \\ 94701 Maisons Alfort
}

\section{RÉSUMÉ}

Une étude épidémiologique portant sur la recherche d'anticorps neutralisant le virus d'Aujeszky a été réalisée au cours de ces deux dernières années dans différentes régions de France. L'étude d'un peu plus de 55 ooo sérums de verrats et truies a révélé la présence de l'infection dans 28 départements à des taux variant entre 2 et 20 p. Ioo par département. L'enquête se poursuit pour évaluer l'évolution de l'infection au cours du temps et devrait servir dès maintenant de base d'information pour une prophylaxie sanitairc rationnelle de la maladie.

\section{SUMMARY}

\author{
EPIDEMIOLOGICAL STUDIFS OF AUJESZKY'S DISEASE \\ IN FRANCE BY DETECTION OF NEUTTRALIZING ANTIBODIES
}

An epidemiological study dealing with detection of antibodies neutralizing the Aujeszky virus has been realized during the last two years in different regions of France. The examination of more than 5 ooo blood sera of boars and sows revealed the existence of the infection in 28 departments and rates varying between 2 and $20 \mathrm{p}$. I oo per department. The investigation is pursued to estimate the evolution of the infection in course sf time and should already now be used as an information basis for a rational sanitary prophylaxis of this disease. 